\title{
Five Times of Cord around Neck in Cesarean Section: A Case Report
}

\author{
Orkun Çetin ${ }^{1}$, İpek Dokurel Çetin², Cihat Şen ${ }^{1}$, Seyfettin Uludağ ${ }^{1}$, Begüm Aydoğan ${ }^{1}$, Aslıhan Ürer \\ ${ }^{1}$ I.Ü. Cerrahpaşa Tip Fakültesi, Kadin Hastalkklarn ve Doğum Anabilim Dal, İstanbul, Türkiye \\ 'İ.Ü. Cerrahpaşa Tip Fakültesi, Çocuk Sağlı̆̆ı ve Hastahklarl Anabilim Dalı, İstanbul, Türkiye
}

\begin{abstract}
Objective: We discussed a rare case of spinal muscular atrophy (SMA) type 0, was followed with prenatal diagnosis of intrauterine growth restriction (IUGR), five times of cord around neck detected during cesarean section, in the highlights of the literature.

Case: A pregnant woman who was followed with the diagnosis of IUGR during 32. gestational week. In the 38. gestational week; cord around neck for five times and a real knot were detected in the cesarean section. Difficulty in swallowing and absorbing, also significant respiratory muscle weakness were found at the follow up of the baby. SMA was suspected according to these symphtoms. With the analyse of PCR RFLP (Polymerase chain reaction - restriction fragment length polymrphism) SMN 1 (Telomeric survival motor neuron gene) homozygot exon 7 and 8 deletions were found, SMA type 0 was diagnosed according to these findings.

Conclusion: During the 2. trimester of pregnacy, with a careful ultrasound examination, cord around neck can be succesfully determined. It should be considered that cord around neck risk rate can be increased in the 3. trimester. Hypotonia, severe respiratory muscle weakness involving the infants to be a good antenatal and postnatal history, examination and molecular study will identify the rare cases of SMA. Genetic counseling should be given to the parents.
\end{abstract}

Keywords: Pregnancy, umblical cord around neck, intrauterine growth retardation, spinal muscular atrophy.

\section{Doğumda boyun çevresinde beş kez kordon dolanmasi: Olgu sunumu}

Amaç: Prenatal dönemde intrauterin gelişme kısıtıı̆ı̆ı (IUGK) tanısı ile takip edilen ve miyadında yapılan sezaryen sırasında boyun çevresinde beş kez kordon dolanması saptanan spinal musküler atrofi (SMA) tip 0 olgusu nadir görülmesi sebebiyle, literatür bilgileri ışığında tartışılmıştır.

Olgu: 32. gebelik haftasından itibaren IUGK tanısı ile takip edilen hastanın, 38. gebelik haftasında yapılan sezaryeni esnasında boyun çevresinde beş kez kordon dolanması ve bir adet gerçek düğüm tespit edildi. Bebeğin izleminde; yutma ve emmede güçlük çekmesi, aynı zamanda solunum kaslarında belirgin güçsüzlük olması üzerine SMA'dan şüphelenildi. PCR RFLP (polymerase chain reaction restriction fragment length polymorphism) yöntemi ile yapılan analizde; SMN 1 (telomerik survival motor nöron geni) homozigot ekzon 7 ve 8 delesyonlarının gösterilmesi üzerine SMA tip 0 tanısı konuldu.

Sonuç: Gebeliğin 2. trimesterinden itibaren yapılan dikkatli bir ultrasonografik inceleme ile umbilikal kordonun fetus boynuna dolanmış olduğu saptanabilir. 3. trimestere yaklaşan haftalarda bu oranın arttığı akılda tutulmalıdır. Hipotoni ve solunum kaslarını da içine alan ağır güçsüzlüğü olan yenidoğanlarda iyi bir antenatal ve postnatal öykünün alınması, muayene bulguları ve moleküler çalışma ile birlikte nadir görülen SMA olgularının tanınmasını ve ailelere gerekli genetik danışmanlığın verilmesi olanağını sağlayacaktır.

Anahtar Sözcükler: Gebelik, boyunda kordon dolanması, intrauterin gelişme kısıtlıı̆ı̆, spinal musküler atrofi.

\section{Introduction}

The coiling of umbilical cord around fetus neck is seen in $23-33 \%$ of all pregnancies and it is generally evaluated as benign. ${ }^{[1,2]}$ It is reported that this situation can be seen at a rate of $6 \%$ on 21 st gestational week. ${ }^{[3]}$ It is less often to observe coiling or knotting of cord around fetus body and extremities. ${ }^{[4,5]}$ 
One of the most frequently seen genetic diseases causing child death around the world is autosomal recessively inherited spinal muscular atrophy (SMA). ${ }^{[6]}$ While SMA was grouped into three sub-groups according to their clinical aspects and beginning age in previous years, Dubowitz defined severe cases (previously classified as SMA Type 1) as SMA 0. SMA Type 0 is clinically characterized severe symmetrical muscle weakness and flaccidity seen much more in lower extremities than upper extremities after birth and affected much more in proximal extremity than distal. Patients frequently require resuscitation and ventilator support at delivery. ${ }^{[6-9]}$

SMA occurs as a result of SMN (survival of motor neuron) gene mutations on long side of 5 th chromosome. ${ }^{[6-10]}$ In this article, SMA Type 0 case which was followed up by IUGR diagnosis in prenatal period and found cord coiled 5 times around neck during cesarean was discussed within the light of literature since it is seen rarely.

\section{Case Report}

Thirty-four years old, G2 P1 pregnant applied to our clinic for routine pregnancy follow-up. Brother of the patient had cerebral palsy, but there was no kin marriage history of the pregnant. At her 1st trimester screening, free beta HCG was 28.3 $\mathrm{ng} / \mathrm{mL}(0.61 \mathrm{MoM})$ and PAPP- A was $0.83 \mathrm{mIU}$ $/ \mathrm{mL}(0.63 \mathrm{MoM})$. In the ultrasonographical examination of fetus at 11th-14th gestational week, it was found that nuchal translucency was $1.9 \mathrm{~mm}$, a wave in ductus venosus blood flow was positive, there was no regurgitation on tricuspid valve, and nasal bone was $1.6 \mathrm{~mm}$. Anatomy and development of fetus was normal. Notches were detected on bilateral uterine arteries. Fixed Down syndrome risk was calculated as 1/8136.

In the ultrasonographical examination of fetus at 22nd gestational week, biparietal diameter (BPD) was found as $54 \mathrm{~mm}$, head circumference (HC) as $201 \mathrm{~mm}$, abdominal circumference (AC) as $166 \mathrm{~mm}$, femur length (FL) as $39 \mathrm{~mm}$, fetal heart beat rate as 138 beat $/ \mathrm{min}$., and a cord existence located on placenta anterior wall and on neck. It was seen that a wave in ductus venosis was positive and there was no regurgitation on tricuspid valve. Notching was continuing on bilateral uterine arteries. Anatomy and development of fetal was observed as normal. 1st hour blood glucose was found as 121 on $50 \mathrm{~g}$ oral glucose tolerance test (OGTT). In the ultrasonographical examination at 32nd gestational week, fetal measurements were found -2 below standard deviation (SD) according to gestational week. Estimated fetal birth weight was $1,352 \mathrm{~g}$, amniotic fluid volume was normal and the patient detected breech presentation was taken to follow-up by IUGR diagnosis. There was cord coiled around neck two times.

The pregnant was followed up by fetal Doppler and non-stress test (NST) due to IUGR diagnosis until 38th gestational week. Single alive 2,230 gr male baby with 1st minute Apgar score 5 and 5th week Apgar score 9 was delivered by cesarean from the 38-weeks-and-3-days patient through cesarean undergone and breech presentation indications. The existence of cord coiled five times around neck (Figure 1) and true knot (Figure 2) was detected during cesarean. In the umbilical vein blood gas taken during delivery, following values were found: $\mathrm{pH} 7.36, \mathrm{PCO}_{2} 38, \mathrm{PO}_{2} 46$, hematocrit 52. Also following values were found in the umbilical artery blood gas: $\mathrm{pH} 7.31, \mathrm{PCO}_{2} 50$, $\mathrm{PO}_{2} 23$, hematocrit 53. Postoperative cord length was measured as $105 \mathrm{~cm}$.

In the newborn examination, body temperature was $35.4{ }^{\circ} \mathrm{C}$ (axillary) and blood pressure was $55 / 35 \mathrm{mmHg}$. There were excessive secretion, certain hypotonia and weakness due to weakness in swallowing muscles. In the radiological examination, chest radiography evaluated as normal. The newborn was dispatched after being followed up for two days in intense care unit. When baby got difficulty to swallow and suck, SMA was suspected. With the analysis of PCR RFLP (Polymerase chain reaction - restriction fragment length polymorphism) SMN 1 (Telomeric survival motor neuron gene) homozygote exon 7 and 8 deletions were found, then SMA type 0 was diagnosed according to these findings.

Patient who was diagnosed as sepsis three times (first one was when only one-month-old) due to pneumonia has still being followed up in pediatric intense care unit by providing respiratory support.

\section{Discussion}

The most frequent location of cord coiling which appears beginning from first trimester in the 


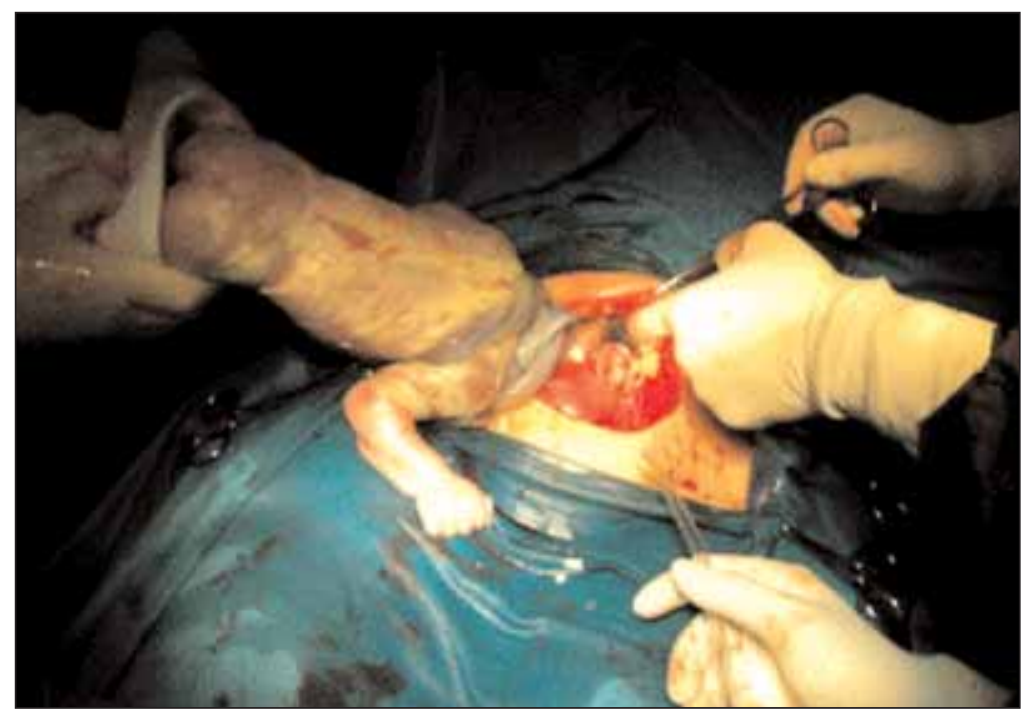

Figure 1. Umbilical cord coiled around neck five times in cesarean section.

pregnancy is the fetal neck circumference. ${ }^{[11]}$ It was reported that cord may coil around neck beginning from the gestational week where cord length reaches $4 / 5$ of fetus length. ${ }^{[12]}$ It was stated that though normal term umbilical cord length is 55-75 $\mathrm{cm}$, it may sometimes be $300 \mathrm{~cm}$ and sometimes aplasia may occur. ${ }^{[21]}$ Cord length is considered as associated with coiling number. ${ }^{[13]}$ In our case, cord length was determined as $105 \mathrm{~cm}$.

When fetus was examined in terms of presentation, it was shown that cord coiling was fre- quently observed in breech presentations. ${ }^{[14]}$ Breech presentation in our case was found as compatible with the literature.

The highest coiling number reported in the literature is nine. ${ }^{[15]}$ In our case, 5 times cord coiling around neck was detected. Cord length, gestational week, placenta localization, fetus weight, fetus mobility and amniotic fluid amount are the factors associated with cord coiling. ${ }^{[12,16]}$ In the literature, there are some studies reporting that placenta being on anterior wall also affects cord coiling. ${ }^{[17]}$

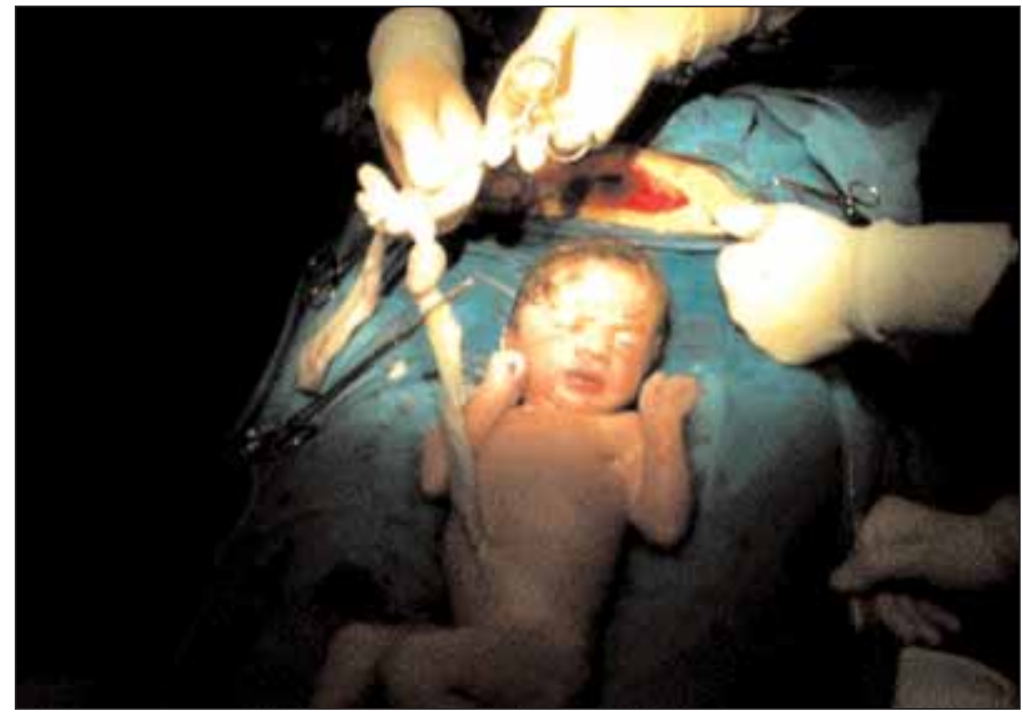

Figure 2. Umbilical cord coiled around neck five times in cesarean section. 
In our case, the placenta was found as anterior wall located.

It was reported that increasing mobility of fetus at third trimester was effective on cord coiling. ${ }^{[13]}$ In our case which was SMA type 0, expectation of fetal mobility decrease was not found as associated with cord coil when it was seen in delivery that cord coiled five times around fetus neck.

Clappa et al. reported that coiling rate increased as gestational weeks advanced. ${ }^{[13]}$ In our case, one time cord coiling was first detected on 22nd gestational week. At 32nd gestational week, two times cord coiling was detected at neck. During the cesarean performed on 38th gestational week, five times cord coiling and one true know were detected.

SMA is a frequently seen neurodegenerative disease where it progresses with the degeneration of anterior horn cells of spinal cord and inherited by autosomal recessive. The prevalence in western societies is $1 / 6,000-1 / 10,000$ and the carrier rate of the disease varies between $1 / 40$ and $1 / 80 .{ }^{[18]}$ SMA's other types as autosomal dominant and inherited according to $\mathrm{X}$ were also defined. ${ }^{[19]}$ In patients who are diagnosed as SMA type 0, asphyxia and generalized weakness are observed in newborn period. Most of them require resuscitation and ventilation support. Bulbar muscles are weak as causing weak crying, weak sucking and swallowing, and aspiration as a result of secretion aggregation. There is frequently fasciculation on tongue. ${ }^{[6-9]}$ In our case, minority of intrauterine fetal movements could not be examined clearly during fetal ultrasonographical examination or anamnesis taken from the mother. However, findings such as hypotonia and weakness were clearly observed during newborn examination. Pneumonia and sepsis developed within the first month were the most significant indication of weakness including respiratory muscles. It was shown in some studies that some of the cases who were diagnosed as having SMA after delivery could be followed by fetal IUGR diagnosis. ${ }^{[20]}$ In our case, IUGR was also observed beginning from 32nd gestational week. The diagnosis was established at postnatal period as in similar studies in the literature.

When other fetal hypocinesia cases were investigated in the literature, it was seen that birth dystocia, short umbilical cord, polyhydramniosis, craniofacial malformations, multiple joint contractures and skeletal anomalies displayed association. ${ }^{[20]}$ In our case, cesarean was preferred as delivery method due to the cesarean history. In our case, unlike the literature, short umbilical cord (actually long umbilical cord was observed), polyhydramniosis, craniofacial malformations and skeletal anomaly were not detected.

In our SMA type-0 case where intrauterine fetal movements were expected to decrease, observing cord coiling five times around neck and true knot during cesarean was not found compatible with the literature. Though it is not frequent to see cord coiling five times around neck in SMA cases, measuring cord length as $105 \mathrm{~cm}$ was considered as it can be explained by breech presentation of the fetus and anterior located placenta. By a careful ultrasonographical examination performed beginning from 2nd trimester of the pregnancy, it can be detected that umbilical cord is coiled around fetus neck. It should be remembered that this rate increases in weeks approaching $3 r d$ trimester. In our case, cord existence around neck was detected by ultrasonographical examinations performed as of 22nd gestational week.

As seen in our case, SMA type-0 is a disease which should be considered first in differential diagnosis in patients who develop severe weakness, hypotonia and respiratory failure at newborn period. Together with examination findings and molecular study, receiving well antenatal and postnatal histories in newborns that have severe weakness including respiratory muscles will enable to know rare SMA cases and to give required genetic consultancy to families.

\section{Conclusion}

By a careful ultrasonographical examination performed beginning from 2nd trimester of the pregnancy, it can be detected that umbilical cord is coiled around fetus neck. It should be remembered that this rate increases in weeks approaching 3rd trimester.

Together with examination findings and molecular study, receiving well antenatal and postnatal histories in newborns that have severe weakness including respiratory muscles will enable to know rare SMA cases and to give required genetic consultancy to families. 


\section{References}

1. Larson JD, Rayburn WF, Crosby S, Thurnau GR. Multiple nuchal cord entanglements and intrapartum complications. Am J Obstet Gynecol 1995;173:1228-31.

2. Ertan AK, Schmidt W. Umbilical cord entanglement and color-coded Doppler ultrasound. Geburtshilfe Franenheilkd 1994;54:196-203.

3. Larson JD, Rayburn WF, Harlan VL. Nuchal cord entanglement and gestational age. Am J Perinatol 1997;14:555-7.

4. Kumari S, Saxena A, Monga D, Malik A, Kabra M, Kurray RM. Significance of cord problems at birth. Indian Pediatr 1992;29:301-5.

5. Miser WF. Outcome of infants born with nuchal cords. $J$ Fam Practice 1992;34:441-5.

6. Dubowitz V. Very severe spinal muscular atrophy (SMA type 0): an expanding clinical phenotype. Eur J Paediatr Neurol 1999;3:49-51.

7. Balslev T, Hertz JM, Rackauskaite G, Sorensen LA. Very severe spinal muscular atrophy- type 0. A cause of congenital multiple arthrogryposis. Ugeskr Laeger 2001;163:5679-80.

8. MacLeod MJ, Taylor JE, Lunt PW, Mathew CG, Robb SA. Prenatal onset spinal muscular atrophy. Eur J Paediatr Neurol 1999;3:65-72.

9. Devriendt K, Lammens M, Schollen E, Van Hole C, Dom R, Devlieger $\mathrm{H}$. Clinical and molecular genetic features of congenital spinal muscular atrophy. Ann Neurol 1996;40:731-8.

10. Bürglen L, Amiel J, Voilett L, Lefebvre S, Burlet P, Clermont O. Survival motor gene deletion in the arthrogryposis multiplex congenita- spinal muscular atrophy association. J Clin Invest 1996; 98: 1130-1132.

11. Yayla M, Sezer FA, Güngören A, Akdeniz N, Erden AC. Gebelikte umbilikal kordon dolanması. Istanbul Jinekoloji ve Obstetrik Dergisi 1997;1:44-6.
12. Collins JH, Collins CL, Weckwerth SR, De Angelis L. Nuchal cords: Timing of prenatal diagnosis and duration. $A m J$ Obstet Gynecol 1995;173:768.

13. Clapp JF, Stepanchak W, Hashimoto K, Ehrenberg H, Lopez B. The natural history of antenatal nuchal cords. Am J Obstet Gynecol 2003;189:488-93.

14. Giacomello F. Ultrasound determination of nuchal cord breech presentation. Am J Obstet Gynecol 1988;159:531-2.

15. Cruikshank DP. Danforth's Obstetrics and Gynecology. Philadelphia: Lippincott Comp., 1994:501-19.

16. Lipitz S, Seidman DS, Gale R, Stevenson DK, Alcalay M, Menczer J, et al. Is fetal growth affected by cord entanglement? J Perinatol 1993;13:385-8.

17. Göynümer G, Yayla M. Gebeliğin ikinci trimesterinde boyun çevresinde kordon dolanması sıklığ1 ve etkileyici faktörler. Perinatoloji Dergisi 2004;12:93-5.

18. Pearn J. Incidence, prevalence, and gene frequency studies of chronic childhood spinal muscular atrophy. J Med Genet 1978;15:409-13.

19. Kobayashi H, Baumbach L, Matise TC, Schiavi A, Greenberg F, Hoffman EP. A gene for a severe lethal form of X-linked arthrogryposis (X-linked infantile spinal muscular atrophy) maps to human chromosome Xp11.3-q11.2. Hum Mol Genet 1995;4:1212-6.

20. Gonzales De Dios J, Martinez Frias ML, Arroyo Carrera I, Fondevilla SJ, Sanchis CA, Hernandez RF, et al. Role of signs of fetal hypokinesia in the diagnosis of spinal muscular atrophy of neonatal onset. An Esp Pediatr 2002;56:23340.

21. Cunningham FG, Gant NF, Leveno KJ, GilstrapIII LC, Hauth JC. Williams Obstetrics. New York: McGraw-Hill Medical Publishing, 2001; 831. 